\title{
Reduced toxicity of malachite green decolorized by laccase produced from Ganoderma sp. rckk-02 under solid-state fermentation
}

\author{
Abha Sharma $\cdot$ Bhuvnesh Shrivastava $\cdot$ \\ Ramesh Chander Kuhad
}

Received: 28 May 2014/Accepted: 30 September 2014/Published online: 11 November 2014

(C) The Author(s) 2014. This article is published with open access at Springerlink.com

\begin{abstract}
Statistical designs were applied for optimizing laccase production from a white-rot fungus, Ganoderma sp. rckk-02 under solid-state fermentation (SSF). Compared to unoptimized conditions [2,154 U/gds (Unit per gram of dry substrate)], the optimization process resulted in a 17.3-fold increase in laccase production $(37,423 \mathrm{U} / \mathrm{gds})$. The laccase produced was evaluated for its potential to decolorize a recalcitrant synthetic dye, malachite green. Laccase at dosage of $30 \mathrm{U} / \mathrm{ml}$ in presence of $1 \mathrm{mM}$ of 1-hydroxybenzotriazole (HBT) almost completely decolorized 100 and $200 \mathrm{mg} / \mathrm{l}$ of malachite green in 16 and $20 \mathrm{~h}$, respectively, at $30{ }^{\circ} \mathrm{C}, \mathrm{pH} 5.5$ and $150 \mathrm{rpm}$. While, higher dyes concentrations of 300,400 and $500 \mathrm{mg} / \mathrm{l}$ were decolorized to 72,62 and $55 \%$ in 24,28 and $32 \mathrm{~h}$, respectively, under similar conditions. Furthermore, it was observed that the decolorized malachite green was less toxic towards the growth of five white-rot fungi tested viz. Crinipellis sp. RCK-1, Ganoderma sp. rckk-02, Coriolopsis Caperata RCK 2011, Phanerochaete chrysosporium K3 and Pycnoporous cinnabarinus $\mathrm{PB}$. The present study demonstrates the potential of Ganoderma sp. rckk-02 to produce high titres of laccase under SSF, which can be exploited in conjunction with redox mediator for the decolorization of high concentrations of malachite green from water bodies.
\end{abstract}

Keywords Decolorization - Detoxification - Ganoderma sp. rckk-02 - Laccase $\cdot$ Malachite green

A. Sharma · B. Shrivastava · R. C. Kuhad $(\square)$ Lignocellulose Biotechnology Laboratory, Department of Microbiology, University of Delhi South Campus, Benito Juarez Road, New Delhi 110021, India

e-mail:kuhad85@gmail.com

\section{Introduction}

Malachite green is a synthetic dye used extensively in aquaculture as a parasiticide/fungicide against protozoan and fungal infections in farmed fish (Maalej-Kammoun et al. 2009). In textile and leather industry, it is used for dying silk, wool, jute and leathers (Gupta et al. 2000). However, the use of this dye generates a lot of concern because of its known toxic effects, including organ damage, mutation and developmental abnormalities in mammals (Gouranchat 2000). The potential human exposure to the dye can occur by consumption of treated fish and by working in dye and aquaculture industry (Cha et al. 2001). The dye also being toxic to micro-organisms affects aquatic ecosystems in an adverse manner (Srivastava et al. 2004). Moreover, the toxic effects of malachite green increase with exposure to time, temperature and concentration as the dye reduces to leuco-malachite green (LeucoMG), whose elimination rate is very slow (Srivastava et al. 2004; Papinutti et al. 2006). Hence, ways to remove excess/ residual malachite green from treatment ponds and industrial effluents need to be explored.

Abiotic methods of dye reduction are known, but their implementation requires expensive catalysts and reagents, which themselves are not environmentally benign (Kuhad et al. 2004). While, use of micro-organisms and the enzymes they secrete is the best route forward for elimination of recalcitrant dyes in an eco-friendly manner (Diwaniyan et al. 2010). Among micro-organisms, whiterot fungi (WRF), group of lignin-degrading basidiomycetous fungi are very efficient in breaking down synthetic dyes as the structure of these dyes is similar to the components that make lignin content in wood (Diwaniyan et al. 2010). However, the microbiological biodegradation of malachite green is difficult because of its fungicidal nature 
(Maalej-Kammoun et al. 2009), thereby preventing implementation of in situ bioremediation strategies for removal of this dye. Alternatively, the isolated ligninolytic enzymes of white-rot fungi can be applied for combating this pollutant as the potential of WRF to degrade lignin and related compounds is due to their extracellular ligninolytic enzyme system comprising of laccase, lignin peroxidase and manganese peroxidase (Murugesan et al. 2007). Out of the three major ligninolytic enzymes produced by WRF, laccases are the most promising ones for various industrial and environmental applications. It is because these enzymes use atmospheric oxygen and release water as the sole by-product and do not require any cofactor or $\mathrm{H}_{2} \mathrm{O}_{2}$ like peroxidases do (Kidwai et al. 2013). Laccase is a polyphenol oxidase that oxidizes polyphneols, methoxysubstituted polyphenols and diamines using the distinctive redox ability of copper ions with the concomitant reduction of molecular oxygen to water (Thurston 1994). However, a major limitation for the commercialization of laccasebased processes is their low production levels and eventually the high cost. Therefore, it is imperative to produce high titres of laccase at low cost, which can be achieved by optimizing culture and fermentation conditions. In this regard, the use of solid-state fermentation (SSF) for enzyme production provides significant economic (Osma et al. 2011) and technical benefits including, high product yields (Kamra and Satyanaryana 2004; Mazumder et al. 2009), use of simple machinery, lesser generation of effluents and lower requirements for agitation (Szendefy et al. 2006). Moreover, the application of statistical designs such as Plackett-Burman design (PBD) for screening of factors that have greatest influence on enzyme production followed by response surface methodology (RSM) for defining their optimum levels is very useful in maximizing enzyme production. Keeping all this in view, the present work was aimed at enhancing laccase production from white-rot fungus Ganoderma sp. rckk-02 by optimizing culture conditions in SSF using statistical designs. The enzyme produced was evaluated for its potential to decolorize malachite green. The decolorized dye was further tested for its reduced toxicity against the growth of some white-rot fungi.

\section{Materials and methods}

\section{Chemicals and raw materials}

All assay reagents were purchased from Sigma-Aldrich (St. Louis, MO, USA), while all media components and dye malachite green were purchased from HiMedia Laboratories Pvt. Ltd. (Mumbai, India). Chemicals used were purchased from Fischer Scientific (Waltham, USA). Wheat bran was obtained locally.

Micro-organisms and culture conditions

P. cinnabarinus $\mathrm{PB}$ and $P$. chrysosporium $\mathrm{K} 3$ were kindly gifted by Dr. K.-E.L Eriksson, Professor Emeritus, Department of Biochemistry and Molecular Biology, University of Georgia, Athens, USA. While, Crinipellis sp. RCK-1 (AM055944), Ganoderma sp. rckk-02 (AJ749970) and Coriolopsis Caperata RCK 2011 (JF283779) were procured from Culture bank, Lignocellulose Biotechnology Laboratory, Department of Microbiology, University of Delhi South Campus. The fungal isolates were grown and maintained on malt extract agar (MEA) containing $(\mathrm{g} / \mathrm{L})$ : Malt extract $20, \mathrm{KH}_{2} \mathrm{PO}_{4} \quad 0.5, \quad \mathrm{Ca}\left(\mathrm{NO}_{3}\right)_{2} \cdot 4 \mathrm{H}_{2} \mathrm{O} \quad 0.5$, $\mathrm{MgSO}_{4} \cdot 7 \mathrm{H}_{2} \mathrm{O}$ 0.5, agar, 20 (pH 5.5.) as described earlier (Diwaniyan et al. 2010). Pure fungal cultures were stored at $4{ }^{\circ} \mathrm{C}$ and subcultured every fortnight.

\section{Laccase production from Ganoderma sp. rckk-02}

SSF for laccase production was carried out in 250-ml Erlenmeyer flasks containing $5.0 \mathrm{~g}$ of wheat bran moistened with mineral salt solution containing $\mathrm{g} / \mathrm{l}$ : $\mathrm{Ca}\left(\mathrm{NO}_{3}\right)_{2} \cdot 4 \mathrm{H}_{2} \mathrm{O}, 0.5 ; \mathrm{KH}_{2} \mathrm{PO}_{4}, 0.5 ; \mathrm{MgSO}_{4} \cdot 7 \mathrm{H}_{2} \mathrm{O}$ in solid substrate to moisture ratio of $1: 3$ as described elsewhere (Sharma et al. 2005). The flasks were inoculated with desired volume of 7-day-old crushed fungal mat (equal to $0.25 / 5 \mathrm{~g}$ of substrate), mixed properly under aseptic conditions and kept at $30{ }^{\circ} \mathrm{C}$. The flasks were patted gently at their bottoms to shake the substrate for air exchange at regular intervals of $24 \mathrm{~h}$ after the onset of fungal mycelial growth. To study the time course of laccase production from the fungus, the fungal fermented bran was removed from the flasks at regular intervals, suspended in citrate buffer ( $\mathrm{pH} 5.5,100 \mathrm{mM}$ ) in fermented solid to liquid ratio of $1: 10$ and shaken gently for $30 \mathrm{~min}$ at $30^{\circ} \mathrm{C}$. The extrudates were squeezed through muslin cloth for maximizing enzyme extraction and centrifuged at $10,000 \mathrm{rpm}$ at $4{ }^{\circ} \mathrm{C}$ for $10 \mathrm{~min}$. The enzyme extract thus obtained was assayed for laccase activity.

\section{Screening of variables using PBD}

Screening of cultural and nutritional parameters (temperature, $\mathrm{pH}$, moisture, inocula size, tryptophan, guaiacol, calcium nitrate, biotin and copper sulfate) influencing laccase production under SSF was carried out employing PBD. This design evaluates the relative importance of various parameters assuming there are no interactions between the factors. Based on the number of variables, experimental design matrix was constructed and analyzed 
Table 1 Plackett-Burman design for laccase production from Ganoderma sp. rckk-02

\begin{tabular}{|c|c|c|c|c|c|c|c|c|c|c|c|c|c|}
\hline Run & $\mathrm{pH}$ & $\begin{array}{l}\text { Temp. } \\
\left({ }^{\circ} \mathrm{C}\right)\end{array}$ & Moisture & $\begin{array}{l}\text { Tryptophan } \\
(\% \mathrm{w} / \mathrm{w})\end{array}$ & $\begin{array}{l}\text { Guaiacol } \\
(\% \text { w/w) }\end{array}$ & $\begin{array}{l}\text { Calcium } \\
\text { nitrate } \\
(\% \mathrm{w} / \mathrm{v})\end{array}$ & $\begin{array}{l}\text { Inocula } \\
\text { size } \\
(\% \mathrm{v} / \mathrm{w})\end{array}$ & $\begin{array}{l}\text { Inocula } \\
\text { age (days) }\end{array}$ & $\begin{array}{l}\text { Biotin } \\
(\% \mathrm{w} / \mathrm{w})\end{array}$ & $\begin{array}{l}\text { Copper } \\
\text { sulfate } \\
(\mathrm{mM})\end{array}$ & D1 & D2 & $\begin{array}{l}\text { Production } \\
\text { (U/gds) }\end{array}$ \\
\hline 1 & 8 & 28 & 4 & 0.1 & 2 & 0.2 & 20 & 10 & 0.1 & 0.5 & 1 & -1 & 5,350 \\
\hline 2 & 8 & 40 & 2 & 0.1 & 0.5 & 0.2 & 20 & 20 & 1 & 0.5 & -1 & 1 & 920 \\
\hline 3 & 4 & 40 & 4 & 0.1 & 0.5 & 0.02 & 20 & 10 & 1 & 2 & 1 & -1 & 6,400 \\
\hline 4 & 8 & 28 & 4 & 1 & 0.5 & 0.02 & 5 & 20 & 1 & 0.5 & 1 & 1 & 10,710 \\
\hline 5 & 8 & 40 & 2 & 0.1 & 2 & 0.02 & 5 & 20 & 0.1 & 2 & 1 & 1 & 4,650 \\
\hline 6 & 8 & 40 & 4 & 1 & 0.5 & 0.2 & 5 & 10 & 0.1 & 2 & -1 & -1 & 11,885 \\
\hline 7 & 4 & 40 & 4 & 1 & 2 & 0.02 & 20 & 20 & 0.1 & 0.5 & -1 & 1 & 11,850 \\
\hline 8 & 4 & 28 & 4 & 0.1 & 2 & 0.2 & 5 & 20 & 1 & 2 & -1 & 1 & 4,640 \\
\hline 9 & 4 & 28 & 2 & 1 & 0.5 & 0.2 & 20 & 20 & 0.1 & 2 & 1 & 1 & 14,335 \\
\hline 10 & 8 & 28 & 2 & 1 & 2 & 0.02 & 20 & 10 & 1 & 2 & -1 & -1 & 7,000 \\
\hline 11 & 4 & 40 & 2 & 1 & 2 & 0.2 & 5 & 10 & 1 & 0.5 & 1 & -1 & 12,225 \\
\hline 12 & 4 & 28 & 2 & 0.1 & 0.5 & 0.02 & 5 & 10 & 0.1 & 0.5 & -1 & -1 & 3,990 \\
\hline
\end{tabular}

using statistical software Design Expert 6.0 (Stat-Ease, Inc. Minneapolis). In the design matrix, each row represents an experiment and each column represents an independent variable, whose levels were varied (Table 1). A total number of $n+1$ experiments were carried out, where $n$ is the number of variables in study. The main effect $\left(E_{\mathrm{xi}}\right)$ of any individual variable is calculated by the difference between the average of response at the high level $(+1)$ and low level $(-1)$. A large main effect (positive or negative) indicates that the variable has a larger impact on the response, while its value close to zero indicates that it does not have any significant effect on the response (Levin et al. 2008).

\section{Optimization of screened variables using RSM}

The significant variables identified by PBD were further optimized by RSM employing a central composite design (CCD). The chosen variables were analyzed at five different levels $(-\alpha,-1,0,+1,+\alpha)$ (Table 2) and different experimental combinations in a total of 20 standard runs (Table 3). The results obtained after CCD were analyzed through standard analysis of variance (ANOVA) and the behavior of the model in terms of mathematical relationship for laccase production was explained using secondorder polynomial equation.

$$
\begin{aligned}
Y= & \beta_{0}+\beta_{1} A+\beta_{2} B+\beta_{3} C+\beta_{11} A^{2}+\beta_{22} B^{2}+\beta_{33} C^{2} \\
& +\beta_{12} A B+\beta_{23} B C+\beta_{13} A C
\end{aligned}
$$

where, $Y$ is predicted response; $\beta_{0}$ is intercept; $\beta_{1}, \beta_{2}, \beta_{3}$ are linear coefficients; $\beta_{11}, \beta_{22}, \beta_{33}$ are squared coefficients and $\beta_{12}, \beta_{23}, \beta_{13}$ are interaction coefficients.
Table 2 Experimental range and levels of independent variables studied by CCD in terms of actual and coded factors

\begin{tabular}{llllllll}
\hline Variable & \multirow{2}{*}{ Units } & Coded value & \multicolumn{6}{l}{ Level of variable } \\
\cline { 5 - 8 } & & & $-\alpha$ & -1 & 0 & +1 & $+\alpha$ \\
\hline Moisture & S:L ratio & $A$ & 1.65 & 2.5 & 3.75 & 5.0 & 5.85 \\
Tryptophan & $\%$ w/w & $B$ & 0.98 & 2.5 & 3.75 & 5.0 & 6.02 \\
Copper & $\mathrm{mM}$ & $C$ & 0.48 & 1.5 & 3.0 & 4.5 & 5.52 \\
\hline
\end{tabular}

Fisher's test was employed for checking the statistical significance of the equation. The quality of the fit of the equation was determined by coefficient of determination $\left(R^{2}\right)$ and the adequacy of the model was checked by plotting a normal probability plot.

Estimation of laccase activity

Laccase activity was estimated using guaiacol as substrate as described elsewhere (Diwaniyan et al. 2010). A change in absorbance of $0.01 \mathrm{~min}^{-1} \mathrm{ml}^{-1}$ at $470 \mathrm{~nm}$ was defined as one unit of laccase activity (U).

Decolorization of malachite green by laccase from Ganoderma sp. rckk-02

Effect of mediator on decolorization of malachite green by laccase

To study the effect of mediator on decolorization of malachite green by laccase, $20 \mathrm{U} / \mathrm{ml}$ of the enzyme was added to $50.0 \mathrm{ml}$ of the dye solution $(100 \mathrm{mg} / \mathrm{l}, \mathrm{pH} 5.5)$ with and without $1 \mathrm{mM}$ HBT and kept at $30^{\circ} \mathrm{C}, 150 \mathrm{rpm}$ for $36 \mathrm{~h}$. Decolorization of Malachite green was recorded 
Table 3 Experimental design and results of central composite design of response surface methodology using three independent variables

\begin{tabular}{llllrr}
\hline Run & Moisture & $\begin{array}{l}\text { Tryptophan } \\
(\% \mathrm{w} / \mathrm{w})\end{array}$ & $\begin{array}{l}\text { Copper } \\
(\mathrm{mM})\end{array}$ & \multicolumn{2}{c}{ Laccase production (U/gds) } \\
\cline { 5 - 6 } & & & & Experimental & Predicted \\
\hline 1 & 2.5 & 2.0 & 1.5 & $12,354.11$ & $12,149.67$ \\
2 & 5.0 & 2.0 & 1.5 & $7,562.09$ & $7,829.82$ \\
3 & 2.5 & 5.0 & 1.5 & $17,899.56$ & $18,322.00$ \\
4 & 5.0 & 5.0 & 1.5 & $23,467.24$ & $23,701.66$ \\
5 & 2.5 & 2.0 & 4.5 & $37,112.15$ & $37,423.36$ \\
6 & 5.0 & 2.0 & 4.5 & $15,402.38$ & $15,525.01$ \\
7 & 2.5 & 5.0 & 4.5 & $23,456.00$ & $23,734.19$ \\
8 & 5.0 & 5.0 & 4.5 & $10,785.76$ & $11,535.35$ \\
9 & 1.65 & 3.5 & 3.0 & $17,709.01$ & $17,491.66$ \\
10 & 5.85 & 3.5 & 3.0 & $4,156.87$ & $3,601.15$ \\
11 & 3.75 & 0.98 & 3.0 & $24,103.12$ & $24,070.21$ \\
12 & 3.75 & 6.02 & 3.0 & $26,645.15$ & $25,905.61$ \\
13 & 3.75 & 3.5 & 0.48 & $15,767.66$ & $15,601.43$ \\
14 & 3.75 & 3.5 & 5.52 & $27,230.19$ & $26,623.38$ \\
15 & 3.75 & 3.5 & 3.0 & $20,782.46$ & $20,606.75$ \\
16 & 3.75 & 3.5 & 3.0 & $20,050.84$ & $20,606.75$ \\
17 & 3.75 & 3.5 & 3.0 & $20,476.00$ & $20,606.75$ \\
18 & 3.75 & 3.5 & 3.0 & $20,980.15$ & $20,606.75$ \\
19 & 3.75 & 3.5 & 3.0 & $20,657.64$ & $20,606.75$ \\
20 & 3.75 & 3.5 & 3.0 & $20,563.00$ & $20,606.75$ \\
\hline
\end{tabular}

spectrophotometrically at $619 \mathrm{~nm}$ ( $\lambda_{\max }$ for malachite green) using a UV-vis spectrophotometer (Analytik-Jena Specord 205). The control sample containing citrate phosphate buffer (pH 5.5) in place of enzyme was run in parallel. The percentage of decolorization was calculated as follows:

Percentage of decolorization $(\%)$

$$
=\left(A_{\mathrm{c}}-A_{\mathrm{t}}\right) / A_{\mathrm{c}} \times 100
$$

where, $A_{\mathrm{c}}$ is the absorbance of the control and, $A_{\mathrm{t}}$ is the absorbance of the test sample.

\section{Effect of enzyme dose on decolorization of malachite green by laccase}

The effect of laccase dose on decolorization of malachite green was studied by incubating $100 \mathrm{mg} / \mathrm{l}$ of dye solution (pH 5.5) with different enzyme activity levels $(10-40 \mathrm{U} / \mathrm{ml})$ at $30{ }^{\circ} \mathrm{C}$ and $150 \mathrm{rpm}$. Percentage decolorization was measured in regular intervals of $4 \mathrm{~h}$ for $36 \mathrm{~h}$.

\section{Effect of dye concentration on decolorization of malachite green by laccase}

The effect of malachite green concentration on its decolorization by laccase was studied at different dye concentrations ranging from 100 to $500 \mathrm{mg} / \mathrm{l}$. Reaction mixtures ( $\mathrm{pH}$ 5.5) containing different dye concentrations were incubated with $30 \mathrm{U} / \mathrm{ml}$ of laccase at $30{ }^{\circ} \mathrm{C}$ and $150 \mathrm{rpm}$. Percentage decolorization was measured in regular intervals of $4 \mathrm{~h}$ for $36 \mathrm{~h}$.

Evaluation of malachite green toxicity towards fungi

Five fungal isolates namely, Crinipellis sp. RCK $-1, C$. caperata RCK 2011, Ganoderma sp. rckk-02, P. chrysosporium $\mathrm{K} 3$ and $P$. cinnabarinus $\mathrm{PB}$ were grown on MEA amended with different concentrations of malachite green $(100-500 \mathrm{mg} / \mathrm{l})$ and incubated at $30^{\circ} \mathrm{C}$ for 7 days. Control experiments in which fungal isolates were grown on MEA were also run in parallel. Radial growth in all the plates was measured at four positions from the point of inoculation and average was taken.

Fungal viability on decolorized malachite green

Malachite green at concentrations ranging from 100 to $500 \mathrm{mg} / \mathrm{l}$ was pre-treated with $30 \mathrm{U} / \mathrm{ml}$ of laccase in presence of $1 \mathrm{mM}$ HBT for 16, 20, 24, 28 and $32 \mathrm{~h}$, respectively, and incorporated into MEA medium. All the fungal cultures were grown on this media and incubated at $30{ }^{\circ} \mathrm{C}$ for 7 days. Radial growth in all the plates was measured at four positions from the point of inoculation and average was taken.

\section{Results and discussion}

Laccase production from Ganoderma sp. rckk-02 under SSF

Ganoderma sp. rckk-02 exhibited laccase production after $48 \mathrm{~h}$ of incubation which reached maximum levels [2,154 $\pm 132.56 \mathrm{U} / \mathrm{gds}$ (unit per gram of dry substrate)] after $120 \mathrm{~h}$ of incubation and declined thereafter (Fig. 1).

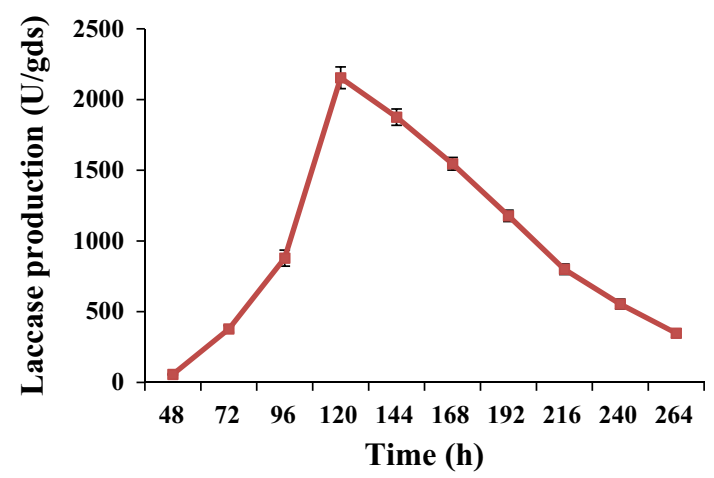

Fig. 1 Time course of laccase production from Ganoderma sp. rckk02 
Table 4 ANOVA for Plackett-burman design

\begin{tabular}{llc}
\hline Variable & Effect & $P$ value $($ Prob $>F)$ \\
\hline $\mathrm{pH}$ & $-2,154$ & 0.008 \\
Temperature & 317 & 0.049 \\
Moisture & 1,285 & $<0.0001$ \\
Tryptophan & $7,009.17$ & $<0.0001$ \\
Guaiacol & -420.83 & 0.092 \\
Calcium nitrate & 792.50 & 0.112 \\
Inocula size & -374.17 & 0.143 \\
Inocula age & 42.50 & 0.067 \\
Biotin & $-1,694.17$ & 0.004 \\
Copper & $2,230.833$ & $<0.0001$ \\
\hline
\end{tabular}

Optimization of laccase production from Ganoderma sp. rckk-02 using statistical designs

\section{Screening of critical variables using PBD}

Among the nine variables tested using PBD, tryptophan, copper and moisture content were significant factors affecting laccase production under SSF with $P<0.0001$ (Table 4). While studying the effect of each factor, tryptophan emerged as the most significant factor by showing highest positive effect $(7,009)$, which was followed by the effect of copper $(2,230)$ and moisture content $(1,285)$ (Table 4). Hence, these three factors viz. moisture (A), tryptophan (B) and copper (C) were selected for further optimization of their levels for laccase production from Ganoderma sp. rckk-02 under SSF by RSM using CCD. A huge difference in laccase production was observed in PBD experiments, showing the necessity of optimization of variables for enhancing enzyme production (Table 1).

\section{Optimization of screened variables by RSM of CCD}

The optimum levels of selected factors (moisture, tryptophan and copper) for maximum enzyme production and the effect of their interactions on the response were determined using RSM of CCD in a set of 20 runs (Table 3). Maximum laccase production $(37,423.36 \mathrm{U} / \mathrm{gds})$ was predicted by the model when the fungus was grown on wheat bran moistened with mineral salt solution in substrate to moisture ratio of 1:2.5 supplemented with $4.5 \mathrm{mM}$ copper and $2.0 \%$ w/w tryptophan (Table 3 ).

\section{Analysis of variance (ANOVA) for response surface model}

The data obtained by RSM were analyzed by ANOVA (Table 5) which gave second-order regression Eq. 2 as a function of initial values of variables for laccase production from Ganoderma sp. rckk-02:
Table 5 Analysis of variance (ANOVA) for response surface model for laccase production

\begin{tabular}{lc}
\hline Term & Value \\
\hline$F$ value* & 390.56 \\
$P>F^{* *}$ & $<0.0001$ \\
$R^{2 \#}$ & 0.9972 \\
Adj $R^{2}$ & 0.9946 \\
Pred $R^{2}$ & 0.9812 \\
Coefficient of variance & 2.78 \\
Adequate precision & 88.825 \\
\hline
\end{tabular}

* The computed $F$ value of 390.56 indicates that there is only a $0.01 \%$ chance that such high-model $F$ value occurs due to noise.

** According to the present model, the model terms $A, B, C, A^{2}, B^{2}$, $A B, A C$ and $B C$ were significant for laccase production exhibiting confidence level above $95 \%(P>F<0.05)$.

\# The determination of coefficient $\left(R^{2}\right)$ was 0.9972 , explaining $99.72 \%$ variability in the response.

$$
\begin{aligned}
Y= & 20606.75-4129.67 A+545.67 B+3,276.84 C \\
& -3556.87 A^{2}+1548.97 B^{2}+178.78 C^{2} \\
& +2424.88 A B-4394.63 A C-4965.38 B C
\end{aligned}
$$

where laccase production $(Y)$ is a function of moisture $(A)$, tryptophan $(B)$ and copper $(C)$.

The similarity between predicted $R^{2}$ and the adjusted $R^{2}$ confirms the adequacy of the model to predict the response (Table 5). Lower value of coefficient of variation depicts greater reliability of the experiments and thus, our value of $2.78 \%$ indicates that the model is reliable. The "Lack of fit $F$ value" of 4.82 tells that the "Lack of fit" was not significant and hence confirming that the model was fit. Adequate precision is an indicator of signal-to-noise ratio and should be greater than 4.0 and our ratio of 88.825 depicts a satisfactory signal. Further, it is extremely important for model to give an adequate fit, which otherwise can lead to prediction of false results. In our case, the adequate fit was satisfied as the normality assumption plot deduced along a straight line giving satisfactory approximation to the test (Fig. 2).

\section{Interaction analysis among variables}

The three-dimensional (3-D) response surface plots of laccase production based on the model were generated for the pair-wise combination of the three factors while keeping the other one at its O-level (Fig. 3a-c). The response surface finds out the optimum level of the selected factors for maximum response and also finds a desirable location in the design space. Figure $3 a$ shows effect of interaction between copper and moisture on laccase production, while Fig. 3b depicts interactive effect of tryptophan and moisture on laccase production. It was observed 


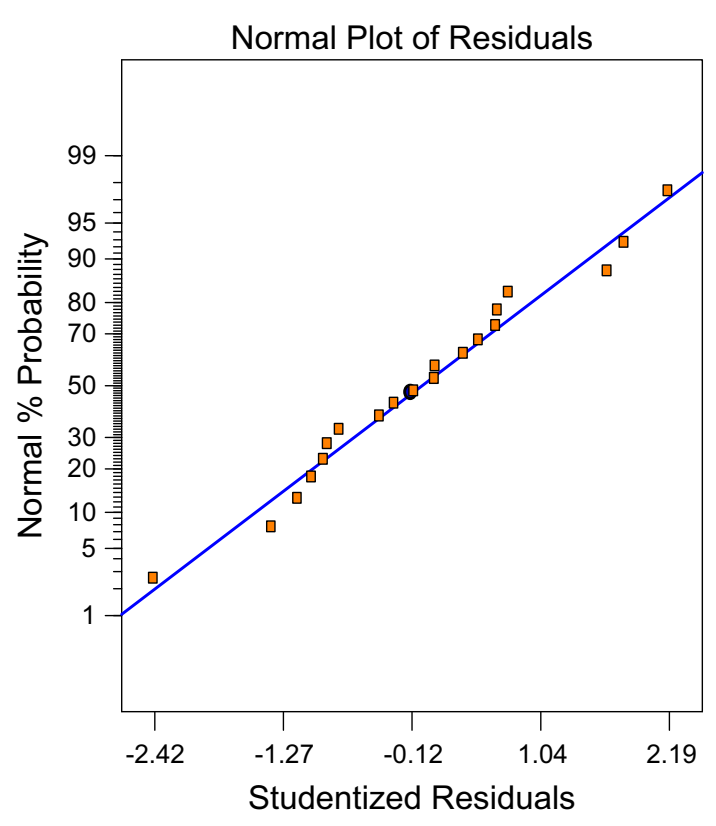

Fig. 2 Residual plot for laccase production

that with increasing initial substrate to moisture ratio from 1:1.65 to $1: 2.5$ (Fig. 3a, b), a considerable increase in enzyme production was observed from Ganoderma sp. rckk-02. While, any further increase in moisture content resulted in a substantial decrease in laccase production. This is because at increased moisture levels, availability of the additives (copper and tryptophan in this case) also increase in the solid medium (wheat bran), resulting in enhanced laccase production. Moreover, at a fixed volume of substrate, increase in water content reduces the air content of the substrate which, in turn affects microbial growth (Battan et al. 2007). While, at lower water levels, the decomposition rate of total organic matter decreases, thereby affecting enzyme production (Raimbault 1998). Patel and co-workers (Patel 2009) have also reported similar effect of moisture on laccase production. Figure $3 \mathrm{c}$ shows interactive effect of copper and tryptophan on laccase production. It was observed from the response curve that laccase production increased significantly on increasing copper and tryptophan concentration from their O-level. This suggests that some positive interaction between copper and tryptophan resulted in increased laccase production from Ganoderma sp. rckk-02. Further, the large value of copper ion concentration shows its inductive effect on laccase production from the white-rot fungus. Moreover, the laccase titres obtained in the present work are much higher than that reported by other workers from white-rot fungi (Table 6), which could be due to supplementation of high concentration of copper to the cultures of Ganoderma sp. rckk-02. Many researchers have shown increased laccase production in presence of copper
(Sadhasivam et al. 2008; Santo et al. 2012; Daassi et al. 2013). However, some reports have also shown that high concentrations of copper have detrimental effect on fungal growth and thus on laccase activity. Lorenzo et al. (2005) observed that copper at $20 \mathrm{mM}$ concentration inhibited laccase production from Trametes versicolor up to $40 \%$. While, Gnanamani et al. (2006) found that $30 \mathrm{mM}$ copper ion enhanced laccase production by 3.5 -fold from $P$. chrysosporium, suggesting that sensitivity to copper varies with the fungal species, acting as inducer for some species and inhibitor for other, also depending on other culture conditions (Gnanamani et al. 2006). In our work, addition of tryptophan, which acts as nitrogen source might also have inhibited the detrimental effect of high concentration of copper $(>2.0 \mathrm{mM})$ on the fungus. Mishra and Kumar (2007) also observed that high concentrations of copper are not inhibitory to the growth of A. nidulans in presence of cyanobacterial biomass which acts as $\mathrm{N}$-supplement to the basic substrate. Diwaniyan et al. (2011) also observed increased laccase production due to positive interaction between copper and tryptophan.

Decolorization of malachite green by laccase from Ganoderma sp. rckk-02

\section{Effect of mediator on decolorization of malachite green by laccase}

The crude laccase from Ganoderma sp. rckk-02 could decolorize $70 \%$ of malachite green within $36 \mathrm{~h}$ in presence of the mediator, HBT $(1 \mathrm{mM})$ while, no decolorization was observed in its absence. This is because the redox potential of fungal laccases ranges from 0.5 to $0.8 \mathrm{~V}$, allowing direct degradation of only low-redox potential phenolic compounds. However, in presence of redox mediators which transfer electrons between laccase and the substrate molecule, even non-phenolic compounds with higher redox potential present in the substrate molecule can be oxidized by laccase (Camarero et al. 2005).

Effect of enzyme dose on decolorization of malachite green by laccase

While studying the effect of enzyme dose on decolorization of $100 \mathrm{mg} / \mathrm{l}$ of malachite green, the rate of dye decolorization increased with increase in enzyme dose from 10 to $30 \mathrm{U} / \mathrm{ml}$ with almost complete decolorization with $30 \mathrm{U} /$ $\mathrm{ml}$ of the enzyme within $16 \mathrm{~h}$ (Fig. 4). However, on further increasing the enzyme dose to $40 \mathrm{U} / \mathrm{ml}$, the rate of decolorization did not increase (Fig. 4). Murugesan et al. (2007) also observed similar results with respect to the effect of laccase dose on dye decolorization. 
Fig. 3 a Response surface plot of laccase production as a function of copper and moisture at fixed tryptophan

concentration of $3.5 \% \mathrm{w} / \mathrm{w}$. b Response surface plot of laccase production as a function of moisture and tryptophan at fixed copper concentration of $3.0 \mathrm{mM}$. c Response surface plot of laccase production as a function of tryptophan and copper at fixed substrate to moisture ratio of 1:3.75 (a) Laccase $X=C:$ CuSO 4
$Y=A:$ Moisture

Actual Factor

B: Tryptophan $=3.50$

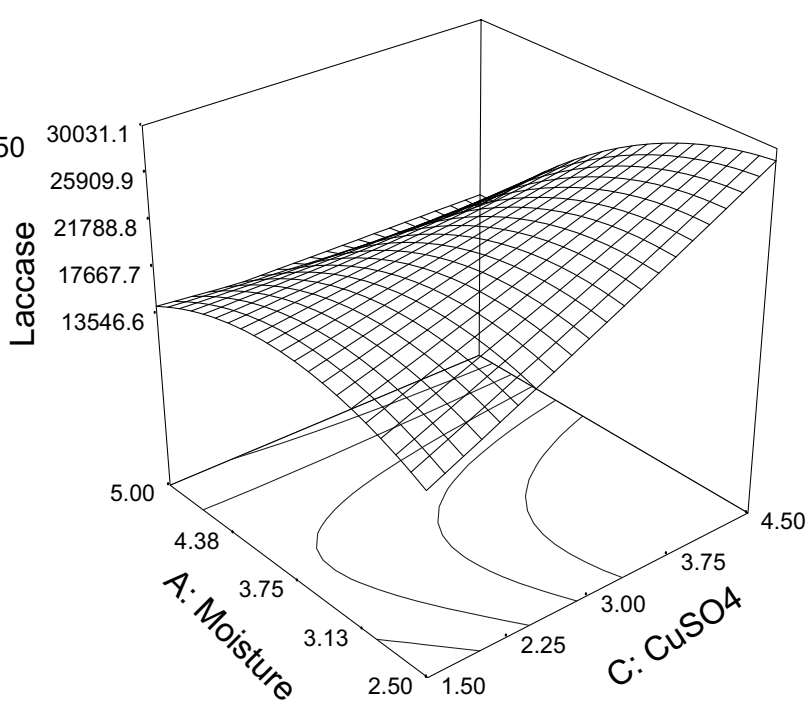

(b) Laccase $X=A$ : Moisture $\mathrm{Y}=\mathrm{B}:$ Tryptophan Actual Factor C: $\mathrm{CuSO} 4=3.00$

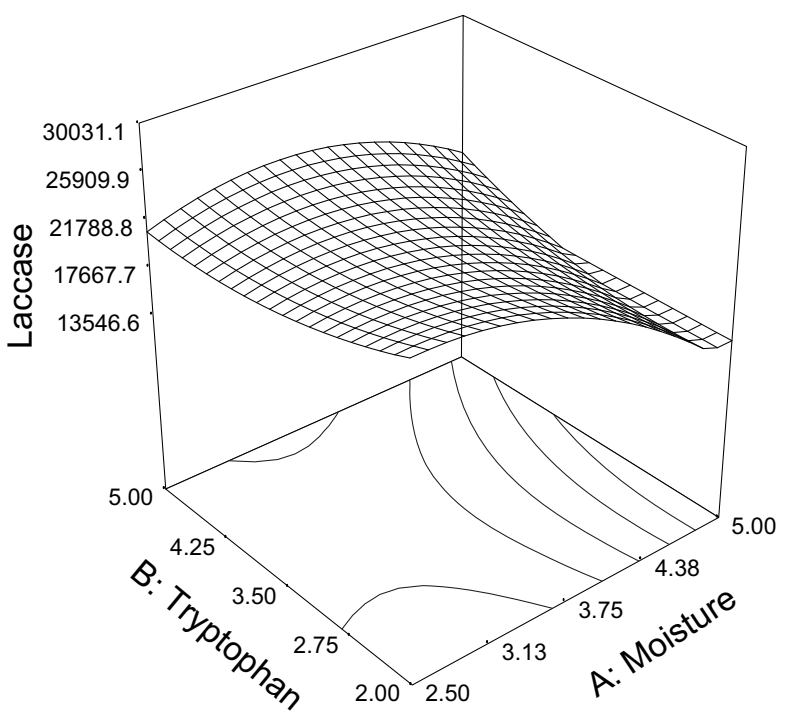

(c) Laccase $\mathrm{X}=\mathrm{B}$ : Tryptophan $\mathrm{Y}=\mathrm{C}: \mathrm{CuSO} 4$

Actual Factor A: Moisture $=3.75$

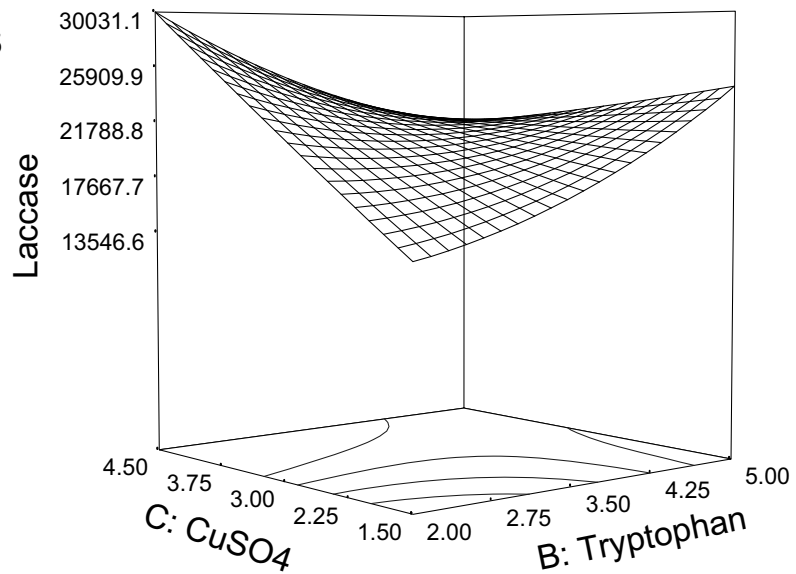


Table 6 Comparison of laccase production under SSF by Ganoderma sp. rckk-02 with other fungi

\begin{tabular}{|c|c|c|c|}
\hline Fungus & Substrate & $\begin{array}{l}\text { Laccase } \\
\text { activity } \\
\text { (U/gds) }\end{array}$ & References \\
\hline P. cinnabarinus & Sugarcane bagasse & 90 & Meza et al. (2005) \\
\hline$P$. sanguineus & Sago hampas & 46.5 & $\begin{array}{l}\text { Vikineswary et al. } \\
\text { (2006) }\end{array}$ \\
\hline Ganoderma sp. & Wheat bran & 10,050 & $\begin{array}{l}\text { Revankar and Lele } \\
\text { (2006) }\end{array}$ \\
\hline G. lucidum & Wheat bran & 2,540 & $\begin{array}{l}\text { Murugesan et al. } \\
\text { (2007) }\end{array}$ \\
\hline T. trogii & Poplar wood & 901 & Levin et al. (2008) \\
\hline P. ostreatus & Wheat bran & 14,189 & Patel et al. (2009) \\
\hline \multirow{4}{*}{$\begin{array}{l}P . \\
\text { chrysosporium }\end{array}$} & a) Brewery waste & 738 & \multirow[t]{4}{*}{ Gassara et al. (2010) } \\
\hline & b) Pomace & 719 & \\
\hline & $\begin{array}{l}\text { c) Pulp and paper } \\
\text { industry sludge }\end{array}$ & 308 & \\
\hline & d) Fishery waste & 94 & \\
\hline T. trogii & Soybean cake & 219 & Zeng et al. (2011) \\
\hline T. versicolor & $\begin{array}{l}\text { Brewer's spent } \\
\text { grain }\end{array}$ & 13,506 & Dhillon et al. (2012) \\
\hline $\begin{array}{l}\text { C. caperata } \\
\text { RCK2011 }\end{array}$ & Wheat bran & $1,576.13$ & Nandal et al. (2013) \\
\hline $\begin{array}{l}\text { Ganoderma sp. } \\
\text { rckk-02 }\end{array}$ & Wheat bran & 37,423 & Present work \\
\hline
\end{tabular}

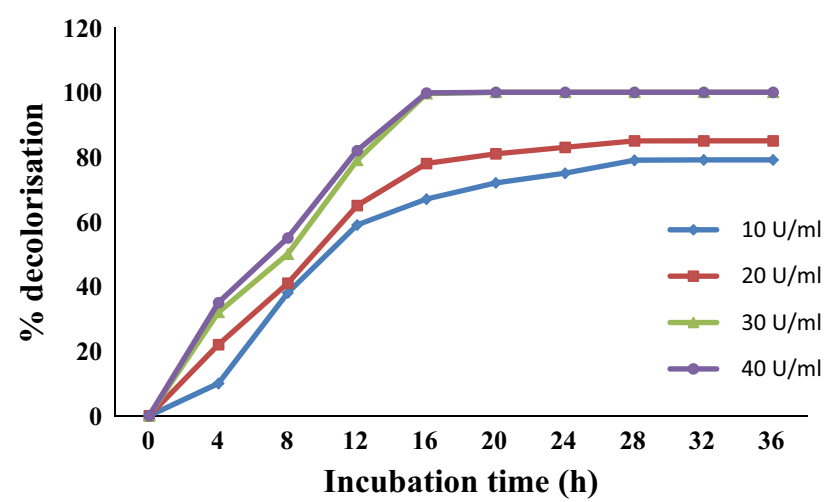

Fig. 4 Effect of laccase dose on decolorization of malachite green $(100 \mathrm{mg} / \mathrm{l})$

Effect of dye concentration on decolorization of malachite green by laccase

On studying the effect of dye concentration (100-500 mg/ 1) on decolorization of malachite green by laccase (30 U/ $\mathrm{ml}$ ), it was observed that on increasing the concentration of dye, percentage of decolorization was slow in the beginning of the experiment, but gradually increased with incubation time up to a point till it became constant
(Fig. 5). While, 100 and $200 \mathrm{mg} / \mathrm{l}$ of the dye were decolorized completely by laccase in 16 and $20 \mathrm{~h}$, respectively, higher dye concentrations of 300, 400 and $500 \mathrm{mg} / \mathrm{l}$ were decolorized to 72, 62 and $55 \%$ in 24, 28 and $32 \mathrm{~h}$, respectively, under similar condition (Fig. 5) Similar results were observed by Satishkumar and co-workers (2010) who inferred that at high concentrations of the dye, efficiency of the enzyme is reduced. The laccase from Ganoderma sp. rckk-02 showed better decolorization rate compared to the laccases from other fungi reported (Table 7). Comparable to our results, Yan and co-workers (2014) reported $98 \%$ decolorization of malachite green ( $200 \mathrm{mg} / \mathrm{L}$ ) in $20 \mathrm{~h}$ by laccase from $T$. trogii. While, there is no report so far on decolorization of malachite green at concentration $>200 \mathrm{mg} / \mathrm{l}$ (Table 7).

Evaluation of malachite green toxicity towards fungi

Among the five fungal isolates used in the present study, $P$. chrysosporium was most sensitive to malachite green with no mycelial growth at any dye concentration (Table 8). While, other fungi could grow in presence of all dye concentrations, although the growth was very less compared to the control (Table 8). Many other workers have also shown toxicity of malachite green towards fungi (Maalej-Kammoun et al. 2009; Papinutti et al. 2006; Sathishkumar et al. 2010) species namely, P. chrysosporium and Trametes sp. Therefore, the presence of this dye in water streams will affect the growth of marine fungi as well. Marine fungi are ecologically, morphologically and physiologically important intermediaries of energy flow between plant detritus and marine fauna (Maira and Sridhar 2006). By white-rot or soft-rot decay, these fungi cause more extensive decay of wood in marine habitats than bacteria (Nambiar et al. 2008). However, all these fungal isolates tested, C. caperata RCK 2011 (Nandal et al. 2013), Crinipellis sp. RCK-1 (Diwaniyan et al. 2011), Ganoderma sp. rckk-02 (Sharma et al. 2013), P. cinnabarinus (Eggert et al. 1997) and P. chrysosporium (Srinivasan et al. 1995), are known producers of laccase. Nevertheless, in presence of dye, the growth of the isolates was retarded and hence laccase was not produced in sufficient amounts for dye decolorization. The difference in growth retardation patterns of the fungal cultures is due to different growth phases in which laccase is produced by each isolate (Papinutti and Forchiassin, 2004). The present work also suggests that removal of malachite green from water bodies is not possible using whole fungal cells as a possible remediation strategy. Therefore, the use of isolated laccase is the best alternative route for elimination of malachite green from water bodies. 
Fig. 5 Effect of dye dose $(100-500 \mathrm{mg} / \mathrm{l})$ on decolorization of malachite green with $30 \mathrm{U} / \mathrm{ml}$ laccase

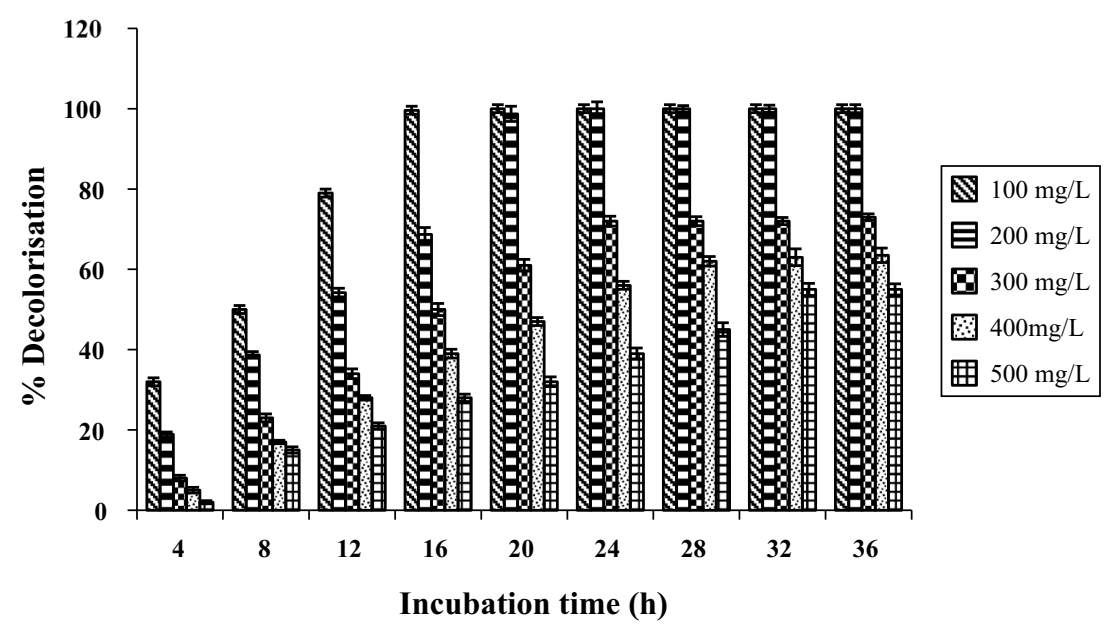

Table 7 Comparison of decolorization of malachite green using laccases from different white-rot fungi

\begin{tabular}{lllll}
\hline Enzyme source & \% Decolorization & Dye concentration $(\mathrm{mg} / \mathrm{L})$ & Time & References \\
\hline Trametes sp. & 80 & 50 & $2 \mathrm{~h}$ & Maalej-Kammoun et al. (2009) \\
T. trogii & 97 & 7 & $74 \mathrm{~h}$ & Levin et al. (2010) \\
T. villosa & 98 & 7 & $24 \mathrm{~h}$ & Levin et al. (2010) \\
C. versicolor & 97 & 7 & $24 \mathrm{~h}$ & Levin et al. (2010) \\
Paraconiothyrium variabile & 60.5 & 60 & $15 \mathrm{~min}$ & Forootanfar et al. (2011) \\
Commercial & 87.32 & 25 & $24 \mathrm{~h}$ & Bibi et al. (2011) \\
T. versicolor & 85 & $22 \mu \mathrm{M}$ & $24 \mathrm{~h}$ & Grassi et al. (2011) \\
P. florida & 96 & 100 & $3 \mathrm{~h}$ & Balan et al. (2012) \\
Trametes trogii & 96 & 150 & $8 \mathrm{~h}$ & Yan et al. (2014) \\
& 100 & 100 & $16 \mathrm{~h}$ & $20 \mathrm{~h}$ \\
Ganoderma sp. rckk-02 & 98 & 200 & $24 \mathrm{~h}$ & Present work \\
& 72 & 300 & $28 \mathrm{~h}$ & $32 \mathrm{~h}$ \\
\end{tabular}

Fungal viability on decolorized malachite green

The radial growth of fungal mycelium in MEA containing laccase-treated malachite green increased compared to the growth in culture media containing untreated dye (Table 8). Therefore, it can be concluded that decolorization of malachite green by laccase from Ganoderma sp. rckk-02 also reduces its toxicity, making it amenable for fungal growth. It was observed that the growth of all the isolates on MEA supplemented with laccase-treated dyes at 100 and $200 \mathrm{mg} / \mathrm{L}$ concentrations was similar to that of the control (Table 8 ). This indicates that reduced toxicity is associated with the degree of color removal from the dye. The pre-treated dyes at these concentrations get almost completely decolorized by laccase (Fig. 4). While, at dye concentrations of more than $200 \mathrm{mg} / \mathrm{l}$, growth was retarded on MEA amended with pre-treated dyes compared to the control, but more than that on media supplemented with untreated dyes (Table 8). This is because at higher dye concentrations, laccase does not remove malachite green completely (72, 62 and $55 \%$ of 300,400 and $500 \mathrm{mg} / \mathrm{l}$ of malachite green) and hence the residual dye in the laccasetreated dye solutions inhibits fungal growth to some extent. Maalej-Kammoun et al. (2009) also showed removal of toxicity of malachite green against $P$. chrysosporium and Trametes sp. after laccase treatment. While, Satishkumar et al. (2010) reported reduced phytotoxicity of malachite green after laccase treatment.

\section{Conclusion}

The decolorization of malachite green by laccase from Ganoderma sp. rckk-02 could be very advantageous for 
Table 8 Radial growth of fungal isolates on MEA supplemented with laccase-treated and -untreated malachite green

\begin{tabular}{|c|c|c|c|}
\hline \multirow[t]{2}{*}{ Fungus } & \multirow{2}{*}{$\begin{array}{l}\text { Malachite } \\
\text { green } \\
\text { concentration } \\
(\mathrm{mg} / \mathrm{L})\end{array}$} & \multicolumn{2}{|l|}{ Diameter $(\mathrm{cm})$} \\
\hline & & $\begin{array}{l}\text { MEA } \\
\text { supplemented } \\
\text { with untreated } \\
\text { dye }\end{array}$ & $\begin{array}{l}\text { MEA } \\
\text { supplemented } \\
\text { with laccase- } \\
\text { treated dye }\end{array}$ \\
\hline \multirow{6}{*}{$\begin{array}{l}\text { Crinipellis sp. } \\
\text { RCK-1 }\end{array}$} & 100 & $5.2 \pm 0.2$ & $7.5 \pm 0.5$ \\
\hline & 200 & $4.5 \pm 0.3$ & $7.2 \pm 0.5$ \\
\hline & 300 & $4.0 \pm 0.2$ & $4.8 \pm 0.4$ \\
\hline & 400 & $3.4 \pm 0.2$ & $4.0 \pm 0.3$ \\
\hline & 500 & $3.0 \pm 0.3$ & $3.6 \pm 0.2$ \\
\hline & Control $^{\mathrm{a}}$ & $8.0 \pm 0.5$ & \\
\hline \multirow{6}{*}{$\begin{array}{l}\text { C. caperata RCK } \\
2011\end{array}$} & 100 & $1.5 \pm 0.2$ & $4.0 \pm 0.3$ \\
\hline & 200 & $1.0 \pm 0.1$ & $3.6 \pm 0.3$ \\
\hline & 300 & $0.7 \pm 0.1$ & $1.1 \pm 0.2$ \\
\hline & 400 & $0.4 \pm 0.02$ & $0.8 \pm 0.3$ \\
\hline & 500 & $0.1 \pm 0.01$ & $0.5 \pm 0.1$ \\
\hline & Control $^{\mathrm{a}}$ & $4.5 \pm 0.2$ & \\
\hline \multirow{6}{*}{$\begin{array}{l}\text { Ganoderma sp. } \\
\text { rckk-02 }\end{array}$} & 100 & $1.3 \pm 0.4$ & $3.6 \pm 0.3$ \\
\hline & 200 & $1.0 \pm 0.2$ & $3.1 \pm 0.3$ \\
\hline & 300 & $0.7 \pm 0.1$ & $1.2 \pm 0.2$ \\
\hline & 400 & $0.5 \pm 0.05$ & $1.0 \pm 0.1$ \\
\hline & 500 & $0.2 \pm 0.01$ & $0.5 \pm 0.07$ \\
\hline & Control $^{\mathrm{a}}$ & $4.0 \pm 0.3$ & \\
\hline \multirow{6}{*}{$\begin{array}{l}\text { P. chrysosporium } \\
\text { K3 }\end{array}$} & 100 & - & $7.4 \pm 0.3$ \\
\hline & 200 & - & $6.9 \pm 0.4$ \\
\hline & 300 & - & - \\
\hline & 400 & - & - \\
\hline & 500 & - & - \\
\hline & Control $^{\mathrm{a}}$ & $8.0 \pm 0.5$ & \\
\hline \multirow{6}{*}{$\begin{array}{l}\text { P. cinnabarinus } \\
\text { PB }\end{array}$} & 100 & $1.0 \pm 0.1$ & $6.1 \pm 0.2$ \\
\hline & 200 & $0.5 \pm 0.03$ & $5.6 \pm 0.3$ \\
\hline & 300 & $0.3 \pm 0.01$ & $0.8 \pm 0.2$ \\
\hline & 400 & $0.1 \pm 0.01$ & $0.6 \pm 0.1$ \\
\hline & 500 & - & $0.4 \pm 0.05$ \\
\hline & Control $^{\mathrm{a}}$ & $6.5 \pm 0.5$ & \\
\hline
\end{tabular}

${ }^{a}$ Control growth of fungus on MEA without the addition of any dye

application of the enzyme in treatment of textile effluents and fish farms. The statistical methods used for optimizing culture conditions helped in enhancing laccase production by several folds under SSF. Higher productions achieved will lead to reduced cost of the enzyme making its commercial viability for bioremediation strategies possible.

Acknowledgments The authors AS and BS acknowledge financial assistance received from Council of Scientific and Industrial Research (CSIR) as senior research fellowship.

Conflict of interest The authors do not have any conflict of interest.
Open Access This article is distributed under the terms of the Creative Commons Attribution License which permits any use, distribution, and reproduction in any medium, provided the original author(s) and the source are credited.

\section{References}

Balan K, Sathishkumar P, Palvannan T (2012) Decolorization of malachite green by laccase: optimization by response surface methodology. J Taiwan Inst Chem Eng 43:776-782

Battan B, Sharma J, Dhiman S, Kuhad RC (2007) Enhanced production of cellulase-free thermostable xylanase by Bacillus pumilus ASH and its potential application in paper industry. Enzym Microb Technol 41:733-739

Bibi I, Bhatti HN, Asgher M (2011) Comparative study of natural and synthetic phenolic compounds as efficient laccase mediators for the transformation of cationic dye. Biochem Eng J 56:225-231

Camarero S, Ibarra D, Martinez MJ, Martinez AT (2005) Ligninderived compounds as efficient laccase mediators for decolorization of different types of recalcitrant dyes. Appl Environ Microbiol 71:1775-1784

Cha C-J, Doerge DR, Cerniglia CE (2001) Biotransformation of malachite green by the fungus Cunninghamella elegans. Appl Environ Microbiol 67:4358-4360

Daassi D, Zouari-Mechichi M, Prieto A, Martinez MJ, Nasri M, Mechichi T (2013) Purification and biochemical characterization of a new alkali-stable laccase from Trametes sp. isolated in Tunisia: role of the enzyme in olive mill waste water treatment. World J Microbiol. doi:10.1007/S11274-013-1380-7

Dhillon GS, Kaur S, Brar SK (2012) In-vitro decolorization of recalcitrant dyes through an ecofriendly approach using laccase rom Trametes versicolor grown on brewer's spent grain. Int Biodeterior Biodegrad 72:67-75

Diwaniyan S, Kharb D, Raghukumar C, Kuhad RC (2010) Decolorization of synthetic dyes and textile effluents by basidiomycetous fungi. Water Air Soil Pollut 210:409-419

Diwaniyan S, Sharma KK, Kuhad RC (2011) Laccase from an alkalitolerant basidiomycetes Crinipellis sp. RCK-1: production optimization by response surface methodology. J Basic Microbiol 51:1-11

Eggert C, Temp U, Eriksson K-EL (1997) Laccase is essential for lignin degradation by the white rot fungus Pycnoporous cinnabarinus. FEBS Lett 407:89-92

Forootanfar H, Faramarzi MA, Shahverdi AR, Yazdi MT (2011) Purification and biochemical characterization of extracellular laccase from the ascomycete Paraconiothyrium variabile. Bioresour Technol 102:1808-1814

Gassara F, Brar SK, Tyagi RD, Verma M, Surampalli RY (2010) Screening of agro-industrial wastes to produce ligninolytic enzymes by Phanerochaete chrysosporium. Biochem Eng J 49:388-394

Gnanamani A, Jayaprakashvel M, Arulmani M, Sadulla S (2006) Effect of inducers and culturing processes on laccase synthesis in Phanerochaete chrysosporium NCIM 1197 and the constitutive expression of laccase isozymes. Enzym Microb Technol 38:1017-1021

Gouranchat C (2000) Malachite green in fish culture (state of the art and perspectives). Bibliographic studies. Ecole Natl. Veterinaire ENVT, Nantes, pp 142

Grassi E, Scodeller P, Filiel N, Carballo R, Levin L (2011) Potential of Trametes trogii culture fluids and its purified laccase for the decolorization of different types of recalcitrant dyes without the 
addition of redox mediators. Int Biodeterior Biodegrad 65:635-643

Gupta VK, Mittal A, Krishnan L, Gajbe V (2000) Adsorption kinetics and column operations for the removal and recovery of malachite green from waste water using bottomash. Sep Purif Technol 40:87-96

Kamra P, Satyanaryana T (2004) Xylanase production by the thermophilic mold Humicola lanuginose in solid-state fermentation. Appl Biochem Biotechnol 1:145-157

Kidwai M, Jain A, Sharma A, Kuhad RC (2013) Laccase catalyzed reaction between meldrum's acid and catechols/hydroquinoesan investigation. C R Chim 16:728-735

Kuhad RC, Sood N, Tripathi KK, Singh A, Ward OP (2004) Developments in microbial methods for the treatments of dye effluents. Adv Appl Microbiol 56:185-213

Levin L, Herrmann C, Papinutti VL (2008) Optimization of lignocellulolytic enzyme production by the white-rot fungus Trametes trogii in solid-state fermentation using response surface methodology. Biochem Eng J 39:207-214

Levin L, Melignani E, Ramos AM (2010) Effect of nitrogen sources and vitamins on ligninolytic enzyme production by some whiterot fungi. Dye decolorization by selected culture filtrates. Bioresour Technol 101:4554-4563

Lorenzo M, Moldes D, Couto SR, Sanroman MA (2005) Inhibition of laccase activity from Trametes versicolor by heavy metals and organic compounds. Chemosphere 60:1124-1128

Maalej-Kammoun M, Zouari-Mechichi H, Belbahri L, Woodward S, Mechichi T (2009) Malachite green decolourization and detoxification by the laccase from a newly isolated strain of Trametes sp. Int Biodeterior Biodegrad 63:600-606

Maira GL, Sridhar KR (2006) Fungal diversity on mangrove woody litter Rhizophora mucronata (Rhizophoraceae). Indian J Mar Sci 35:318-325

Mazumder S, Basu SK, Mukherjee M (2009) Laccase production in solid state and submerged fermentation by Pleurotus ostreatus. Eng Life Sci 9:45-52

Meza JC, Lomascolo A, Casalot L, Sigoillot J-C, Auria R (2005) Laccase production by Pycnoporus cinnabarinus grown on sugar-cane bagasse: influence of ethanol vapours as inducer. Process Biochem 40:3365-3371

Mishra A, Kumar S (2007) Cyanobacterial biomass as N-supplement to agro-waste fir hyper-production of laccase from $P$. ostreatus in solid-state fermentation. Process Biochem 42:681-685

Murugesan K, Nam KI-H, Kim Y-M, Chang Y-S (2007) Decolorization of reactive dyes by a thermostable laccase produced by Ganoderma lucidum in solid state culture. Enzym Microb Technol 40:1662-1672

Nambiar GR, Raveendran K, Changzing Z, Jaleel CA (2008) A glimpse of lignicolous marine fungi occurring in coastal bodies of Tamil Nadu (India). C R Biol 331:475-480

Nandal P, Ravella SR, Kuhad RC (2013) Laccase production by Coriolopsis caperata RCK2011: optimization under solid state fermentation by Taguchi DOE methodology. Sci Rep. doi:10. 1038/Srep01386

Osma JF, Toca-Herrera JL, Rodríguez-Couto S (2011) Cost analysis in laccase production. J Environ 92:2907-2912

Papinutti VL, Forchiassin F (2004) Modification of malachite green by Fomes sclerodermeus and reduction of toxicity to Phanerochaete chrysosporium. FEMS Microbiol Lett 231:205-209
Papinutti VL, Mouso N, Forchiassin F (2006) Removal and degradation of the fungicide dye malachite green from aqueous solution using the system wheat bran-Fomes sclerodermeus. Enzym Microb Technol 39:848-853

Patel H, Gupte A, Gupte S (2009) Effect of different culture conditions and inducers on production of laccase by a basidiomycetes fungal isolate Pleurotus ostreatus HP-1 under solidstate fermentation. BioResources 4:268-284

Raimbault M (1998) General and microbiological aspects of solid substrate fermentation. Electron J Biotechnol 1:174-189

Revankar MS, Lele SS (2006) Enhanced production of laccase using a new isolate of white rot fungus WR-1. Process Biochem 41:581-588

Sadhasivam S, Savitha S, Swaminathan K, Lin F-H (2008) Production, purification and characterization of mid-redox potential laccase from a newly isolated Trichoderma harzianum WL1. Process Biochem 43:736-742

Santo M, Weitsman R, Sivan A (2012) The role of the copper-binding enzyme laccase in the biodegradation of polyethylene by the actinomycete Rhodococcus rubber. Int Biodeterior Biodegrad. doi:10.1016/j.ibiod.2012.03.001

Satishkumar P, Murugesan K, Palvannan T (2010) Production of laccase from Pleurotus florida using agro-wastes and efficient decolorization of Reactive blue 198. J Basic Microbiol 50:360-367

Sharma KK, Kapoor M, Kuhad RC (2005) In vivo enzymatic digestion, in vitro xylanase digestion, metabolic analogues, surfactants and polyethylene glycol ameliorate laccase production from Ganoderma sp. kk-02. Lett Appl Microbiol 41:24-31

Sharma KK, Shrivastava B, Satry VRB, Sehgal N, Kuhad RC (2013) Middle-redox potential laccase from Ganoderma sp.: its application in improvement of feed for monogastric animals. Sci Rep 3:1299. doi:10.1038/srep01299

Srinivasan C, DSouza TM, Boominatahn K, Reddy CA (1995) Demonstration of laccase in the white rot basidiomycete Phanerochaete chrysosporium BKM-F1767. Appl Environ Microbiol 61:4274-4277

Srivastava S, Sinha R, Roy D (2004) Toxicological effects of malachite green. Aquat Toxicol 66:319-329

Szendefy J, Szakacs G, Christopher L (2006) Potential of solid-state fermentation enzymes of Aspergillus oryzae in biobleaching of paper pulp. Enzym Microb Technol 39:1354-1360

Thurston CF (1994) The structure and function of fungal laccases. Microbiol 140:19-26

Vikineswary S, Abdullah N, Renuvathani M, Sekaran M, Pandey A, Jones EBG (2006) Productivity of laccase in solid substrate fermentation of selected agro-residues by Pycnoporus sanguineus. Bioresour Technol 97:171-177

Yan J, Niu J, Chen D, Chen Y, Irbis C (2014) Screening of Trametes strains for efficient decolorization of malachite green at high temperatures and ionic concentrations. Int Biodeterior Biodegrad 87:109-115

Zeng X, Cai Y, Lia X, Zeng X, Li W, Zhang D (2011) Decolorization of synthetic dyes by crude laccase from a newly isolated Trametes trogii strain cultivated on solid agro-industrial residue. J Hazard Mater 187:517-525 